\title{
Cooling Load and Exergy Destruction Analysis in Air Conditioning Operation Room with Ambient Temperature Variation
}

\author{
Eflita Yohana ${ }^{1, *}$, Revki Romadhon ${ }^{1}$, Binawan Luhung ${ }^{1}$, Irwan Fernando ${ }^{1}$, and M.S.K. Tony Suryo Utomo ${ }^{1}$ \\ ${ }^{1}$ Department of Mechanical Engineering, Faculty of Engineering, Diponegoro University, Semarang - Indonesia
}

\begin{abstract}
HVAC installations are essential to the operating room to maintain the safety of environmental conditions and provide comfort for patients and medical personnel. Operating room is a room with a class of 10,000 where the maximum number of particles in the room is 352,000 particles per cubic feet for bacteria 0.5-micrometer size (ISO 14644-1). To achieve the desired air conditions in the operating room required an air conditioning tool that is Air Handling Unit (AHU). The AHU determination shall be adjusted to the cooling load of the chamber derived from the sensible load and latent load. Exergy analysis is required to optimize a process and evaluate the device performance. The purpose of this study is to calculate the cooling load and perform the analysis of exergy destruction on Cooling Coil and Electric Heater in AHU. The calculation of cooling load uses the standard air change method. Exergy analysis uses the second law of thermodynamic concepts related to entropy. The results obtained cooling load and exergy destruction increases with the increase of ambient temperature. Maximum exergy destruction in cooling coil 1 and 2 at $35^{\circ} \mathrm{C}$ is $3.3 \mathrm{~kW}$ and $1.6 \mathrm{~kW}$ while in the electric heater is $0.52 \mathrm{~kW}$.
\end{abstract}

Keywords: Air change; Air Handling Unit; Cooling Coil; Electric Heater; Exergy; HVAC.

\section{Introduction}

HVAC (Heating, Ventilation, and Air Conditioning) systems at health care facilities provide services to support populations vulnerable to increased health and safety hazards. Healthcare facilities are characterized by high levels of modification due to the science and healthcare economies by consuming large amounts of energy (HCACE 2003). The operating room is one of the special units in the hospital that serves as a place to perform surgery that requires sterile conditions and other special conditions. In a publication of the American Society of Heating, Refrigerating and Air-conditioning Engineers (ASHRAE), the HVAC Design Manual for Hospitals and Clinics shows that there are certain considerations for the design of the operating room. The HVAC requirements for the operating room consist of the following: regulating temperature, humidity, air pressure, supplied air filtration, allowable air circulation, and the effectiveness of air system delivery options [1].

Research by Balaras, Descalaki, and Gaglia in 2006 [2] describes the need for efficiency in HVAC installations to maintain the safety of the surrounding environment for patients and medical personnel. From the results of writing, it is known that the problems contained in the operating room are insufficient indoor air exchange, low control of indoor thermal conditions and poor ergonomics that affect the ventilation system.
Therefore a careful planning of the air-conditioning system in the operating room is necessary for safety and comfort.

The cooling load is the total amount of heat energy that must be eliminated in units of time from the desired space. Cooling loads are adjusting the cooling requirements of the operating room and use energy in the air conditioning tool efficiently [3]. Energy consumption of a machine is an essential parameters in industrial sectors. Exergy analysis uses mass conservation laws and energy conservation along with the second law of thermodynamics for the design and analysis of energy systems. Exergy analysis can reveal the performance and enhance the potential of each component in a system significantly. One of the applications of exergy analysis is on Air Conditioning system. AHU (Air Handling Unit) is an air conditioning tool with several components in it.

Research by M. Ghazikhani, I. Khazaee, and S. Vahidifar in 2016 [4] has a purpose to know the influence of outside air temperature and outside air humidity at the rate of destruction of exergy flowing in AHU component (Air Handling Unit). In their research, they use 2 methods, namely constant temperature, and constant enthalpy. The results of this study showed that the destruction of the exergy on the cooling coil increases with the higher ambient temperature while the

* Corresponding author: efnan2003@gmail.com 
destruction in the heating coil does not change significantly with the increase of ambient temperature.

By knowing the importance of HVAC planning in the operating room, this study has the purpose of designing the operating room air-conditioning system with cooling load analysis and exergy analysis on airconditioning devices. By doing an exergy analysis it can be known how much energy is destroyed and cannot be utilized. The more efficient the operating room design will enhance the energy saving that lead to less use of fossil energy.

\section{Experiment}

\subsection{Room design}

The operating room used in the study is an operating room with a semi-open system. Semi-open systems are systems where conditioned air is partly external and partially recirculated from within the operating room. Recommendations from the FGI Guidelines (AGI 2010) and ANSI / ASHRAE / ASHE Standard 170-2008 The number of air supply entering the operating room is 20 $\mathrm{ACH}$ (air changes per hour) [5]. The operating room in this study has the following dimensions:
- Length $\quad: 8 \mathrm{~m}$
- Wide : $6 \mathrm{~m}$
- Ceiling Height $: 3.5 \mathrm{~m}$
- Floor Area $: 48 \mathrm{~m}^{2}=517 \mathrm{ft}^{2}$
- Room Volume : $168 \mathrm{~m}^{3}=5932 \mathrm{ft}^{3}$

In this study, AHU used has several important components namely House of Mixing, Filter, Pre Cooling, After Cooling, Heating Coil and Booster Fan. In this study, air conditioning equipment using the system using 2 cooling coils and 1 electric heater for heating.

\subsection{Methodology research}

Figure 1 describes the research step in the form of a flowchart.

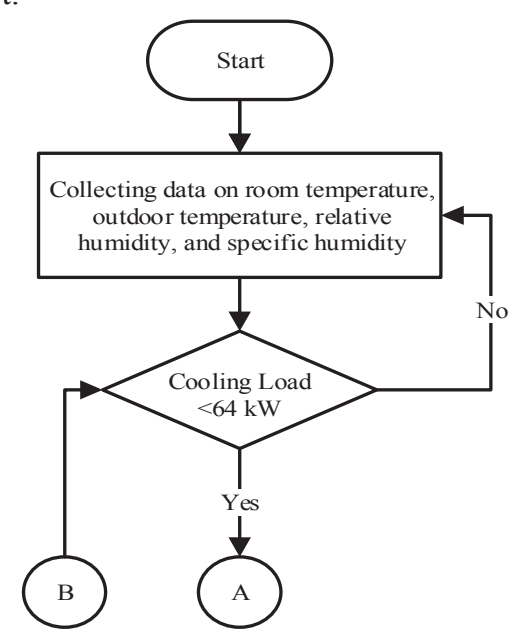

Fig. 1. Methodology research

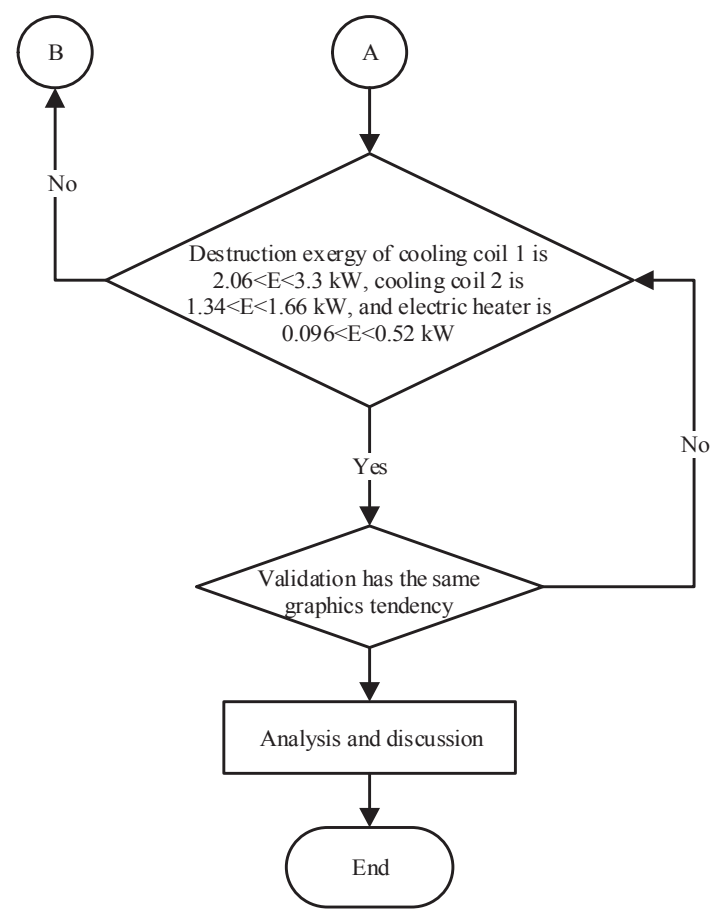

Fig. 1. Methodology research (continued)

\subsection{Cooling load analysis}

The standard air change approach method is used in the calculation of cooling loads. This method will produce an overall cooling load value from outside and indoors and is a fast method of determining air conditioning devices. The cooling load calculated in this study is the peak load of the operating room with the assumption of conditions as in Table 1. The air change per hour in the operating room is sourced from the Health Care Facilities, ASHRAE Applications Handbook 1999 [6]. Air capacity entering the room through air change can be known through equation 1 .

$$
\mathrm{CFM}=\mathrm{V} \times \mathrm{f}_{\mathrm{ac}} \times 35.31 / 60
$$

To calculate the sensible heat and latent heat using equation 2 to equation 5 .

$$
\begin{gathered}
\mathrm{SH}=\mathrm{CFM} \times 60 \times 0.075 \times 0.24 \times\left(\mathrm{T}_{\mathrm{o}}-\mathrm{T}_{\mathrm{i}}\right) \\
\mathrm{SH}=\mathrm{CFM} \times 1.08\left(\mathrm{~T}_{\mathrm{oa}}-\mathrm{T}_{\mathrm{rm}}\right) \\
\mathrm{LH}=\mathrm{CFM} \times 60 \times 0.075 \times 1076 \times 1 / 7000\left(\omega_{\mathrm{o}}-\omega_{\mathrm{i}}\right) \\
\mathrm{LH}=\mathrm{CFM} \times 0.68\left(\omega_{\mathrm{oa}}-\omega_{\mathrm{rm}}\right)
\end{gathered}
$$

A value of $0.075 \mathrm{lb} /$ cubic feet is the average air density value using a system of return and supply of water and specific heat of $0.24 \mathrm{BTU} / \mathrm{lb} / \mathrm{f}, 1076$ (BTU / $\mathrm{lb}$ ) is a difference of enthalpy of $50 \mathrm{~F}$ condensed vapor from $75 \mathrm{~F}$ water vapor after in coil, and 1/7000 (Grains/lb) is the conversion unit weight of dry air. To find the total heat value of the overall load then look for Grand total heat as in equation 6 .

$$
\mathrm{TSH}=\mathrm{SH}+\mathrm{LH}
$$


Table 1. Condition of planning

\begin{tabular}{|c|c|c|}
\hline Condition & Temperature & \%RH \\
\hline Outdoor Air & $89.6 \mathrm{~F}$ & $70 \%$ \\
\hline Return Air & $71.6 \mathrm{~F}$ & $60 \%$ \\
\hline Mixed Air & $75.2 \mathrm{~F}$ & $65 \%$ \\
\hline Room Air & $68 \mathrm{~F}$ & $50 \%$ \\
\hline
\end{tabular}

\subsection{Exergy analysis in AHU}

In this study, the exergy analysis just in some components contained in AHU (Air Handling Unit) such as cooling coil and electric heater. The air coming from the mixing house will go into a cooling coil system 1 . The air is cooled through the refrigerant medium until it reaches a lower temperature of the mixed air resulting in convection and conduction heat transfer. The air coming out of the cooling coil 1 will then go into cooling coil 2 to have a lower air temperature. Once out of the cooling coil 2, then the air into the electric heater to raise the temperature and reduce air humidity. The number of exergy in this study is the exergy from the air and the exergy from the refrigerant. In this plan, the assumption of air used is an approximation of the ideal gas constants and has the same pressure value of each process. While the refrigerant used is type R410-A. Table 2 represents air and water vapor data with ideal gas constants [7].

Table 2. Ideal gas constants of dry air (a) and water vapor (v)

\begin{tabular}{|c|c|}
\hline Dry Air (a) & Water Vapor (v) \\
\hline $\mathrm{R}_{\mathrm{a}}=0.287 \mathrm{~kJ} /(\mathrm{kg} \cdot \mathrm{K})$ & $\mathrm{R}_{\mathrm{v}}=0.4615 \mathrm{~kJ} /(\mathrm{kg} \cdot \mathrm{K})$ \\
\hline $\mathrm{c}_{\mathrm{p}, \mathrm{a}}=1.003 \mathrm{~kJ} /(\mathrm{kg} \cdot \mathrm{K})$ & $\mathrm{c}_{\mathrm{p}, \mathrm{v}}=1.872 \mathrm{~kJ} /(\mathrm{kg} \cdot \mathrm{K})$ \\
\hline $\mathrm{M}_{\mathrm{a}}=28.97 \mathrm{~kg} / \mathrm{kmol}$ & $\mathrm{M}_{\mathrm{v}}=28.97 \mathrm{~kg} / \mathrm{kmol}$ \\
\hline$\overline{\mathrm{R}}_{\mathrm{a}}=8.314 \mathrm{~kJ} /(\mathrm{kmol} . \mathrm{K})$ & $\overline{\mathrm{R}}_{\mathrm{v}}=8.314 \mathrm{~kJ} /(\mathrm{kmol} . \mathrm{K})$ \\
\hline$\overline{\mathrm{c}}_{\mathrm{p}, \mathrm{a}}=29.057 \mathrm{~kJ} /(\mathrm{kmol} . \mathrm{K})$ & $\overline{\mathrm{c}}_{\mathrm{p}, \mathrm{v}}=33.724 \mathrm{~kJ} /(\mathrm{kmol} . \mathrm{K})$ \\
\hline
\end{tabular}

In this study shows the use of the concept of exergy on air conditioning system applications. The object of an exergy application in an air-conditioning system is to bring the moist air mixture to a state different from that found in atmospheric air. In equation 7 can be seen the total value of the specific flow of exergy per kilogram of dry air.

$$
\begin{gathered}
e_{\mathrm{t}}=\left(c_{\mathrm{p}, \mathrm{a}}+\omega \cdot c_{\mathrm{p}, \mathrm{v}}\right) \mathrm{T}_{\mathrm{o}}\left(\frac{\mathrm{T}}{\mathrm{T}_{\mathrm{i}}}-1-\ln \frac{\mathrm{T}_{\mathrm{o}}}{\mathrm{T}_{\mathrm{i}}}\right)+(1+\varpi) \mathrm{R}_{\mathrm{a}} \mathrm{T}_{\mathrm{o}} \ln \frac{\mathrm{p}}{\mathrm{p}_{\mathrm{o}}} \\
+\mathrm{R}_{\mathrm{a}} \mathrm{T}_{\mathrm{o}}\left[(1+\varpi) \ln \frac{1+\Phi_{\mathrm{o}}}{1+\varpi}+\varpi \ln \frac{\Phi}{\varpi_{\mathrm{o}}}\right]
\end{gathered}
$$

The total value of the specific exergy flow per kilogram of refrigerant can be searched by equation 8 .

$$
e_{\mathrm{xr}, \text { in }}=h_{\mathrm{in}}-h_{\mathrm{o}}-\mathrm{T}_{\mathrm{o}}\left(s_{\mathrm{in}}-s_{\mathrm{o}}\right)
$$

The balance of exergy on cooling coil and electric heater can be calculated using equation 9 and equation 10 .

$$
\begin{gathered}
\dot{\mathrm{m}}_{\mathrm{a}}\left(e_{\mathrm{x}, \text { in }}\right)-\dot{\mathrm{m}}_{a}\left(e_{\mathrm{x}, \text { out }}\right)+\dot{\mathrm{m}}_{\mathrm{r}}\left(e_{\mathrm{xr}, \text { in }}\right)-\dot{\mathrm{m}}_{\mathrm{r}}\left(e_{\mathrm{xr}, \text { out }}\right) \\
+\dot{\mathrm{Q}}\left(1+\frac{\mathrm{T}_{\mathrm{o}}}{\mathrm{T}_{\mathrm{i}}}\right)-\dot{\mathrm{E}}_{\mathrm{des}}=0 \\
\dot{\mathrm{m}}_{\mathrm{a}}\left(e_{\mathrm{x}, \text { in }}\right)-\dot{\mathrm{m}}_{\mathrm{a}}\left(e_{\mathrm{x}, \text { out }}\right)+\dot{\mathrm{Q}}\left(1+\frac{\mathrm{T}_{\mathrm{o}}}{\mathrm{T}_{\mathrm{i}}}\right)-\dot{\mathrm{E}}_{\mathrm{des}}=0
\end{gathered}
$$

\section{Result and discussion}

Total cooling load value or grand total heat has increased along with the increase in ambient temperature as in Figure 2. This is because the greater the difference in outdoor and indoor temperature, the greater the work required by the cooling machine to achieve room temperature.

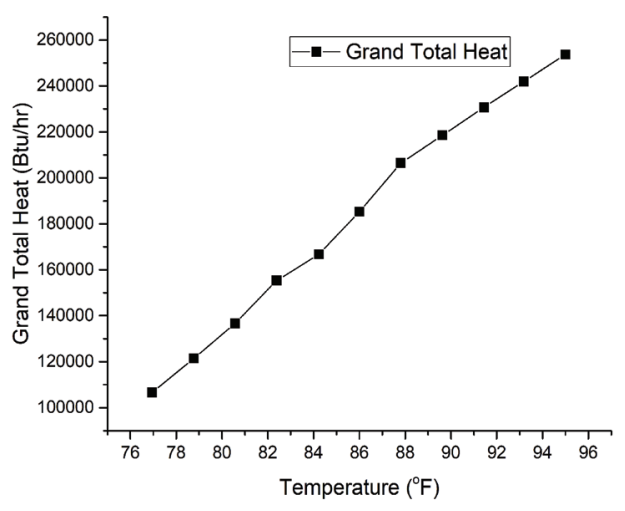

Fig. 2. Graphic of GTH and Ambient Temperature

The value of exergy destruction on cooling coil 1 and 2 has increased along with the increase of ambient temperature as in Figure 3 and Figure 4. In cooling coil and electric heater, the higher ambient temperature will be the greater the potential difference in temperature cooling process in both cooling coil and electric heater so it needs a lot of exergies to maintain the temperature in the system. This leads to increased irreversibility where more exergy is discharged into the environment. The value of the destruction of the electric heater as shown in Figure 5. This is due to a slight loss of exergy or irreversibility.

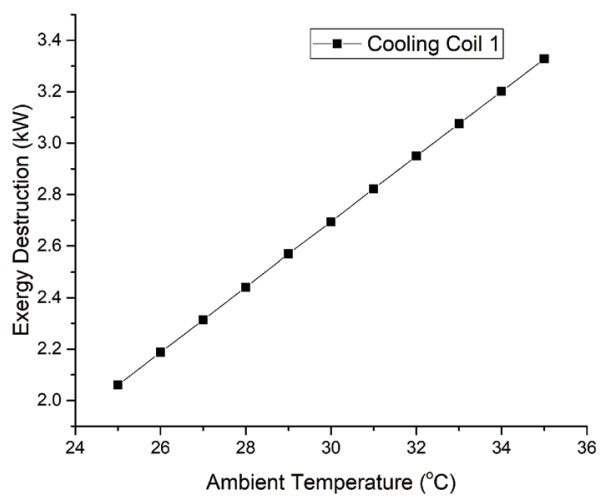

Fig. 3. Graphic of Exergy Destruction in Cooling Coil 1 vs Ambient Temperature 


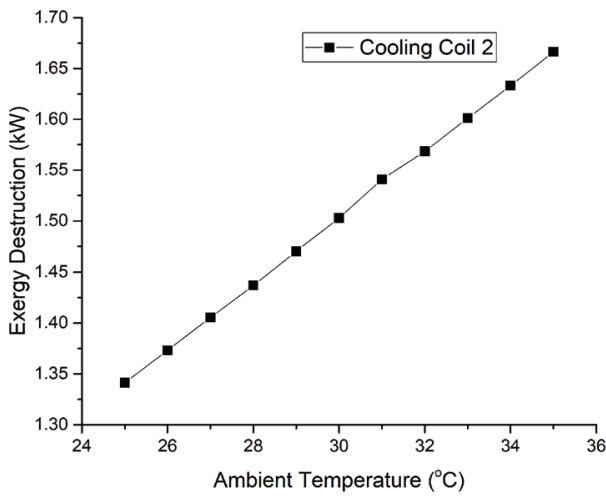

Fig. 4. Graphic of Exergy Destruction in Cooling Coil 2 vs Ambient Temperature

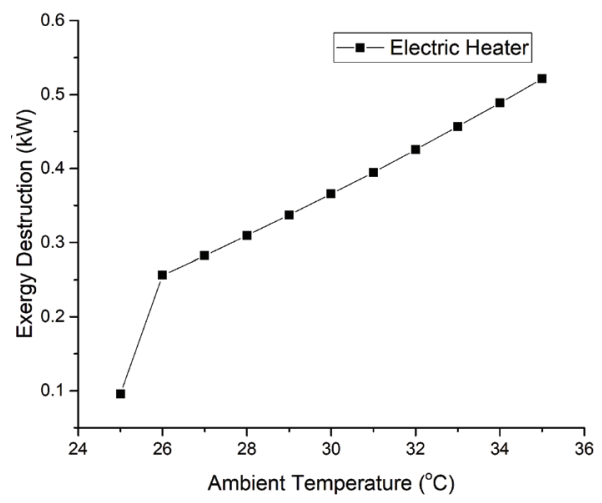

Fig. 5. Graphic of Exergy Destruction in Electric Heater vs Ambient Temperature

The research journal used for the validation of this final project is the research conducted by M.Ghazikhani, I. Khazaee, and S.Vahidifar in 2016 [4]. In this study, the researcher looks for the influence of the destruction of exergy to the effect of ambient temperature as shown in Figure 6.

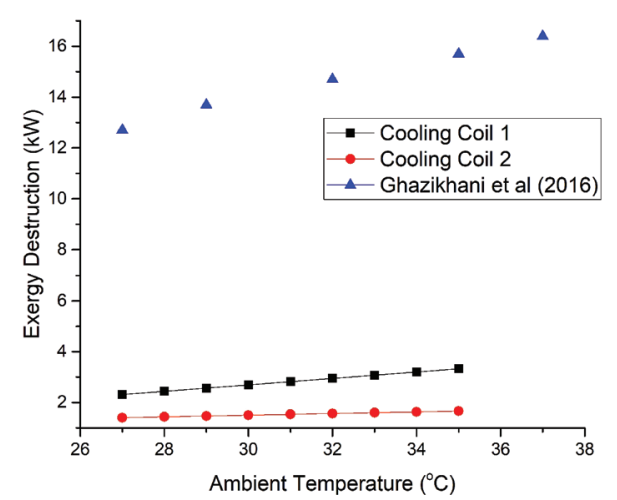

Fig. 6. Comparative Graphics of Research and Previous Research
Figure 6 illustrates that the destruction of exergy has increased to ambient temperature. This is because the ambient temperature will affect the rate of exergy on a system. The blue graph illustrates the magnitude of the rate of exergy destruction in the journal, while the black, red graph describes the value of exergy destruction in this study which has the same tendency to increase in the cooling coil.

\section{Conclusion}

The conclusion obtained from the analysis that has been done is the value of cooling load on ambient temperature variation of temperature $77 \mathrm{~F}\left(25^{\circ} \mathrm{C}\right)-95 \mathrm{~F}\left(35^{\circ} \mathrm{C}\right)$ has the greatest value $253.100 \mathrm{Btu} / \mathrm{hr}$. With the calculation method used, the cooling load will increase with large ambient temperature. At ambient temperature variation, the highest destruction exergy of cooling coil 1 at temperature $35^{\circ} \mathrm{C}$ is $3.3 \mathrm{~kW}$, the highest destruction exergy of cooling coil 2 at temperature $35^{\circ} \mathrm{C}$ is $1.66 \mathrm{~kW}$. The value of exergy destruction on the cooling coil increases with the effect of rising ambient temperature as the greater the temperature difference potential in the cooling coil cooling process leading to increased irreversibility. The highest destruction value of electric heater at temperature $35^{\circ} \mathrm{C}$ is $0.52 \mathrm{~kW}$.

\section{References}

1. M. Geshwiler, HVAC Design Manual for Hospitals and Clinics. ASHRAE (2003)

2. C. A. Balaras, E. Dascalaki, and A. Gaglia, "HVAC and indoor thermal conditions in hospital operating rooms," Energy Build., 39, no. 4, pp. 454-470 (2006)

3. K. Anwar, "Efek Beban Pendingin terhadap Performa Sistem Mesin Pendingin," J. SMARTek, 8, no. 3, p. 203 (2010)

4. M. Ghazikhani, I. Khazaee, and S. Vahidifar, "Exergy analysis of two humidification process methods in air-conditioning systems," Energy Build., 124, pp. 129-140 (2016)

5. A. Bhatia, "HVAC Design for Cleanroom Facilities," no. 877 (2012)

6. ASHRAE, "ASHRAE Handbook-Fundamentals," ASHRAE Handbook-Fundamentals, p. 21.1-21.67 (2009)

7. A. Bejan, G. Tsatsaronis, and M. Moran, Thermal Design and Optimization

(1996) 